\title{
Death and Immortality_An Everlasting Puzzle: A Comparative Analysis of Emily Dickinson's Two Poems
}

\author{
Qigang Liu ${ }^{1}$ \\ ${ }^{1}$ School of Applied English Studies, Shandong University of Finance and Economics, Jinan, China \\ Correspondence: Qigang Liu, School of Applied English Studies, Shandong University of Finance and \\ Economics, No. 7366, ErHuanDong Road, LiXia District, Jinan, Shandong Province, China. E-mail: \\ ANGELIC_L312@126.com
}

Received: April 6, $2016 \quad$ Accepted: April 26, $2016 \quad$ Online Published: May 18, 2016
doi:10.5539/ells.v6n2p172
URL: http://dx.doi.org/10.5539/ells.v6n2p172

\begin{abstract}
Emily Dickinson as a religious poet was obsessed with the subject of death and immortality; about third of her poems feature this enigma which baffles not only the ordinary multitudes but also those great thinking minds throughout the human history. But up to now, it remains by and large a matter of belief, and people's belief is subject to vacillation, especially so when this elusive subject is concerned. Emily Dickinson is no exception. This article makes use of close reading as its analyzing method. By way of detailed examinations on the semantic ambiguity and uncertainty of particular words, the narrative incoherence revealed in the unusual change of tenses as well as the inconsistency in the image of Death, it reveals that Dickinson, like many other great thinking minds, held an ambivalent attitude towards death and immortality. As a matter of fact, what can be deduced from all her poems on this enigma is an obsessed spirit which was questioning, doubting while at the same time believing.
\end{abstract}

Keywords: Emily Dickinson, death, immortality, fly, light, puzzle

\section{Introduction}

Emily Dickinson, almost unknown as a poet in her lifetime, is now recognized as one of the greatest and most original poets in American literature. Dickinson's poetic style is highly original, characterized by its conciseness, directness, and simple diction and syntax. Her poems are short but rich in meanings. As to subject matters, by far the largest portion of Dickinson's poetry dwells on death and immortality, themes which lie at the center of Dickinson's world. The reason for Dickinson's obsession about these themes is not far to seek when we take into account her family background.

As a matter of fact, the fact that Emily Dickinson was born into a Calvinist family made her inevitably and forever concerned with religious subject matters. While still studying at the Mount Holyoke Seminary, which was strongly Congregational, Dickinson refused to observe its religious customs. She "found herself unable to 'convert' - that is, to experience a conviction of faith and to testify to her experience before the assembled church" (Cayne, 1971, p. 80). Calvinism with its doctrine of predestination and its pessimism pressured her during her childhood and adolescence and tainted her work so that her basic tone was tragic, although sometimes with short-lived intermittent optimistic illusions. Through her poetry on these religious subject matters she expressed a passionate desire for religious certitude, a desire that can never be fulfilled. The loss of faith, the religious uncertainty, which harassed so many intelligent and thinking minds, was apparently assailing Dickinson, as well. The God of the Bible is not always real to her, she didn't always believe in God's plan for an afterlife; she could not reconcile with the belief that God is benevolent while He permits evil to exist with His omniscience, omnipresence and omnipotence.

In many of Dickinson's poems, she acted like a Job, always questioning the benevolence of God and even His very existence. Unlike her family, she refused to go to church, but her overt protest against the religious doctrine should not and can not be interpreted as her farewell to religious concerns. On the contrary, during her entire life, she was always obsessed by these religious issues such as the very existence of God, salvation and immortality after death. She was always believing as well as doubting; her ambivalent attitude towards God is well illustrated in her two poems on death. One is "Because I Could Not Stop for Death", the other being "I Heard a Fly Buzz-When I Died." 


\section{An Analysis of the Poem "Because I Could Not Stop for Death"}

\section{The "Kindly" Is Not That Kind}

In the first two lines of "Because I Could Not Stop for Death". Death, personified as a gentleman like carriage driver, stops for one who could not stop for him, the word "kindly" is particularly meaningful, for the coming of death is more often considered to be grim and horrible. Then, why does Dickinson deliberately use "kindly" to characterize the arrival of death? The answer seems self-evident when we associate it with her religious belief of salvation and immortality after death, the line "He kindly stopped for me-" can be interpreted as: Death stopped his carriage for the speaker to pick her up to carry her to salvation and immortality, in order to stress this point, the third and fourth lines continue to explain that Death has another passenger in his carriage-Immortality and the poet deliberately let "And Immortality" stands alone to emphasize the fact that the speaker's journey after death is accompanied by immortality. This interpretation seems all good and well, but it won't withstand further investigation. Firstly, the first line "Because I Could Not Stop for Death" invites such a question as why the speaker could not stop for death, and the answer to this question may shed a new light on the understanding of "kindly." There is only one way to stop for death voluntarily, that is suicide, but given to the fact that suicide is conceived of as a cardinal sin in most religious beliefs, it's really not an advisable option. So there is nothing left to do but wait patiently for the arrival of Death, in such case, the final arrival of Death naturally becomes a welcome and kind act. Interpreted this way, what is felt more strongly in the word "kindly" is a tone of helplessness and melancholy rather than of gratitude or ecstasy. Moreover, what sort of person would see the arrival of death as a welcome and kind act? There are two kinds of people who may well fit into this category; one would be those who might have suffered enough from this life and see death as a means of escape. The other kind would be those who have firm conviction in the salvation and immortality of the soul after death. In light of the ambivalent tone of the word "kindly", both instances may apply to the speaker in the poem. But that is not all about "kindly", the semantic tension of this word extends actually to the entire poem.

In the second stanza, the poet continues to state the speaker's willingness to go with Death and again stresses His kindness:

We slowly drove- - He knew no haste

And I had put away

My labors and my leisure too,

For His Civility-

This stanza can be interpreted as the speaker's expression of her desire for immortality, in order to achieve immortality after death, "I had put away/ My labor and my leisure too", that is, the speaker deserted all her earthly concerns. So far, so good, but in the fourth stanza of the poem, things become problematic:

The dews grew quivering and chill,

For only gossamer my gown,

My tippet only tulle.

It's apparent that the speaker is not properly dressed for the journey; she is wearing only a gossamer gown and tulle tippet, and she feels cold. At this point, the kindness and civility of Death is put into question, what sort of gentleman would take a lady out for a journey in such a haste that she is even not allowed the time to dress herself properly? No wonder some critics view the death here as a "deceiver, perhaps even a rapist to carry her off to destruction" (Marcus, 1982, p. 88). This might be a bit too far-fetched, but there is an element of tyranny in his act, at least, he is not that kind. What's also worth mentioning here is the image of the dew, as Freedman (2001) points out, "Dew is a fitting reminder of the Christian's Baptism into Christ's death and resurrection" (p. 134), but the dew in this poem is deprived of its divine powers, it just "grew quivering and chill" just as the dew does in reality after night falls.

\subsection{The Journey of the Soul and its Destination}

Superficially, the journey of the soul is described as a pleasant journey. The driver-Death is kind, accompanied by Immortality, the longed-for company with death, the beautiful scene on the journey, "the school where children played", "the fields of gazing grain", "the setting sun", the soul is in full possession of her vision, spiritual one if not physical. She can not only see the spiritual things, Death, Immortality, the carriage and the horse but also see the physical things, the playing children, the gazing grain (obviously symbolizes maturity), the setting sun (symbolizes the later time of life), which are seen in chronological order, symbolizing man's youth, adulthood and old age. All in all, the soul is in full possession of vision, which is a prerequisite for her witness to 
immortality after death and an evidence of immortality itself.

However, in the last stanza of the poem, the speaker reveals a rather confused status of being although the basic tone remains by and large optimistic.

Since then - 'tis centuries, - and yet

Feels shorter than the day

I first surmised the horses' heads

Were toward eternity-.

The first two lines affirm her immortality after death by saying;

Since then-'tis Centuries, - and yet

Feels shorter than the Day

"Since then" here means after the journey, the speaker feels centuries shorter than a day, because she is now living in a world of immortality. But in the third line, Dickinson deliberately uses the word "surmised" which is modified by "first". Thus the last two lines can be interpreted as: the speaker initially supposed that the horses were heading for eternity. It can be obviously seen here that the sentence is highly suggestive and incomplete in meaning, implying that the speaker's initial conjecture may be wrong and the horses may well be heading for a different destination which is apparently not eternity. And the word "first" in a sense strengthens the possibility of her suspicion that the horses are not heading for eternity at all. What is even more alarming is the application of present tense to the word "feel", which may intrigue readers' curiosity about her present whereabouts. The word "paused" indeed has a connotation that the journey would go on, but the implication of the phrase "since then" and the present tense in the word "feel" can also be taken as a semantic indication that the journey is ended at the tomb- - "A swelling of the ground". Maybe it's just like Fred D. White puts it: "......the presumably dead speaker is merely being driven to heaven without ever arriving there" (Martin, 2002, p. 97). To put it bluntly, the speaker is neither in heaven nor in any celestial place promised in religious doctrines. She is stranded, maybe for eternity, in her tomb.

\subsection{Summary}

All in all, in the poem "Because I Could Not Stop for Death", through a willful play of words and narrative ambiguity, Dickinson successfully builds up a narrative tension which imbues the entire poem with a sense of suspicion and uncertainty. The benevolence of Death is questionable, the destination of the journey is unclear, the present whereabouts of the soul is a mystery, the spiritual quest is mingled with a heavy sense of reality, and the enunciated joy in expectation of salvation is interwoven with the muted undertone of melancholy and disillusionment. Nothing is certain except for the fact that the soul does survive death, which leaves a tinge of hope for the possibility of immortality and salvation. Whereas, in another poem on the same theme of death, Dickinson's attitude towards this religious enigma becomes radically negative. The poem is "I Heard a Fly Buzz-When I Died."

\section{Analysis of the Poem "I Heard a Fly Buzz-When I Died"}

\section{Symbolic Meanings of the Fly and the Light}

In the poem "I Heard a Fly Buzz-When I Died," the experience of death is explicitly gruesome, neither immortality nor salvation is assured or even seen possible. Here, Dickinson seemed disillusioned at her belief of salvation and immortality after death, certainly temporarily not once and for good. This denial is stressed in the poem mainly by two elements. One is the intrusion of the buzzing fly, the other being the use of double "see" at the end of the poem.

The poem develops itself in a dramatic way, after those relatives stopped their mourning, in an atmosphere of outward quietness and inner stoicism, the dying began to sign away her "keepsakes", after the last transaction of the dying, and the poem reaches its dramatic climax in the third stanza. Something extraordinary is expected, that is the coming glory of God, the light or some angels, however, to the despair of the moribund, nothing supernatural came but a buzzing fly which serves as a reminder of the her final, cadaverous condition and putrefaction. Then the poem continues:

With Blue - uncertain stumbling Buzz-

Between the light - and me-

And then the Windows failed - and then 
I could not see to see-

From the capitalized word "Blue", it can be guessed that the fly is a blowfly, which is utterly dirty and ugly. The light in the poem may have double meanings, literally, it refers to the light coming through the window, metaphorically, it means salvation, which is holy and pure, thus the poet deliberately made a sharp contrast between the ugly and dirty blowfly and the holy salvation to achieve a kind of ironic and pathetic effect, the holy is defeated by the earthly, and moreover, here the two dashes in the line "Between the light—and me-_" may serve as a means of showing the dying speaker's mental process of the painful, reluctant but helpless acceptance of the fact that her resolute expectancy of salvation after death is smashed into pieces by the intrusion of such a dirty, ugly and insignificant creature. Thus these two lines can be interpreted as: when the speaker was expecting the arrival of her holy salvation, she was waylaid by a dirty and ugly blowfly, which disillusioned her about her belief of salvation after death, so she gave herself up to unconsciousness.

The fly may also stand for Beelzebub, who is also known as lord of the flies. Sometimes Beelzebub is used as another name for Satan; sometimes it refers to any devil; in Milton's Paradise Lost, Beelzebub is Satan's chief lieutenant in hell. If the symbolic meaning of fly is interpreted in this way, the tone of the poem turns out to be even more tragic and gruesome. For in the poem there is no account of the life deeds of the moribund, whether she is morally good or bad is not mentioned, she is presented here just as an individual human being who can be everybody with a faith in the religious doctrine of salvation after death. In this way, the poem gains a universal significance, that is, be it morally good or bad, believing or doubting, all human beings may meet the same tragic end of life, that is, the impending shadow of the devil rather than the embrace of "the king"-God.

"And then the Windows failed - and then / I could not see to see-" in the last line of the poem, the speaker stressed her disillusionment about her belief of salvation after death by using double "see", "I could not see to see-" here the first "see" is used in its literal meaning, that is , the faculty of sight;"I could not see" means the speaker lost the ability of seeing, "to see" here means the possibility to see what the speaker expected to see, that is, her salvation after death. So the line can be paraphrased to read: "I lost my vision and hence lost the hope to witness salvation after death."

\subsection{The Process of Dying}

The process of dying presented in the poem is much more realistic than that in the poem "Because I Could Not Stop for Death". The mourning relatives, the willing of the keepsakes, the windows, and even the fly altogether constitute a real experience that all human beings will go through. When the symbolic meanings of the concrete things such as the light and the fly are set aside, there is only one spiritual element in the whole poem, namely "the King" whom the dying is waiting for. But this can also be a common spiritual process of any dying human being who has a belief in life after death. The process of dying is real, the fly is real, but the most significant thing for the dying - "the King" is not. Thus the realistic description of the dying process plus the ultimate tragic end of the waiting creates such a pathetic notion — death is death, nothing more.

\subsection{Summary}

In the poem "I Heard A Fly Buzz-When I Died," Dickinson seems to have become even more disillusioned about death and immortality, the undertone of the poem even becomes sarcastic, for the ardently expected King - whatever divine apparition, never shows up, even if the light can be understood as a herald of his arrival, it's nevertheless waylaid by an insignificant creature in reality-the fly, how in any sense could it be possible? Since no divine apparition - whatsoever - shows up, immortality is simply out of the question.

\section{A Comparison between the Two Poems}

Both of the above discussed poems dwell on the theme of death, but Dickinson's interpretations are different. In the first poem, in spite of all the elements of suspicion and uncertainty, the existence of the soul after death is for certain, which leaves a hopeful scope for the possibility of immortality and salvation; whereas, the second poem gives a realistic description of a deathbed scene, the aura of which is entirely pathetic and gloomy, the dying speaker's final hope for the arrival of the "King" is easily thwarted by the intervention of a fly. What is left for the dying speaker is nothing but a helpless acceptance of the loss of consciousness and the putrefaction of the body. It seems that in this poem Dickinson has adopted a nihilistic attitude towards death and immortality, which of course can only be understood as one of the many instances of her vacillating attitudes towards this enigma.

\section{Conclusion}

Death and immortality has always been and will always be a theme in philosophy, theology and literature. For centuries and centuries the great thinking minds have been dwelling on it, but none of them has yet come up with a resolute answer to the question whether there is immortality after death. It is basically a religious issue in 
different forms. Christianity assures its believers of immortality and Heaven as long as they behave in accordance with the words of God; the Buddhism promises a beautiful afterlife through reincarnation as long as the believers are good; Plato believes in the eternal existence of the soul and views death as a mere "separation of soul and body" (Jowett, 2008, p. 334), which is also the prerequisite to attain "the knowledge of true being" (Plato 336), certainly there are many other interpretations belonging to other various cults. But all of them are no more than mere beliefs, and beliefs in themselves are liable to uncertainty. It is this very nature of the belief in immortality after death as well as the mysterious nature of death itself that intrigues the everlasting curiosity of numerous great thinking minds, who were, are and will be forever and ever in the earnest quest for the truth of death and immortality.

Dickinson, being born into a Calvinist family, was doomed to be haunted and troubled by this issue in her entire lifetime. Her ambivalent attitude towards death and immortality is no better revealed than in the two poems analyzed above. The more or less optimistic attitude towards death and immortality in the first poem is smashed into pieces in the second; instead, what is waiting for the dying is no more than the pathetic deprivation of vision and the putrefaction of the body. However, Dickinson's attitude towards death and immortality does not at all reach an unswerving belief in either of the two poems, as a matter of fact, like numerous great thinking minds, she had always been believing as well as doubting throughout her entire life, this ambivalent spirit of Dickinson can also be found in many other her poems on death and immortality. Dickinson had been dead for more than a century, she might have found the answer to death and immortality, but it is impossible for her to come back to tell, the everlasting puzzle is left to us-believing as well as doubting spirits.

\section{References}

Bloom, H. (2008). Bloom's Modern Critical Views-Emily Dickinson (New Edition). New York: Chelsea House Publications.

Cayne, B. S. (1971). Encyclopedia Americana International Edition Volume 9 Desert to Egret. New York: Americana Corporation.

Freedman, L. (2001). Emily Dickinson and the Religious Imagination. New York: Cambridge University Press.

Friedrich, G. et al. (1992). On 465 ("I heard a Fly buzz-when I died-"). Emily Dickinson Journal, 1(1). Retrieved from http://www.english.uiuc.edu/maps/poets/a_f/dickinson/465.htm

Jowett, B. (2008). Works of Plato, 2. Guilin: Guangxi Normal University Press.

Leiter, S. (2007). Critical Companion to Emily Dickinson: A Literary Reference to Her Life and Work. New York: Facts On File Inc.

Marcus, M. (1982). Emily Dickinson: Selected Poems. New York: Hungry Minds, Inc.

Martin, W. (2002). The Cambridge Companion to Emily Dickinson. Cambridge: Cambridge University Press. http://dx.doi.org/10.1017/CCOL0521806445

Smith, M. N., \& Mary, L. (2008). A Companion to Emily Dickinson. USA: Blackwell Publishing Ltd. http://dx.doi.org/10.1111/b.9781405122801.2008.x

\section{Copyrights}

Copyright for this article is retained by the author(s), with first publication rights granted to the journal.

This is an open-access article distributed under the terms and conditions of the Creative Commons Attribution license (http://creativecommons.org/licenses/by/3.0/). 